\title{
Effect of Thermal Pretreatment on the Solubilization of Organic Matters in a Mixture of Primary and Waste Activated Sludge
}

\author{
A. M. Aboulfotoh ${ }^{a} *$, E. H. El Gohary ${ }^{a}$, O. D. El Monayeri ${ }^{b}$ \\ ${ }^{a}$ Environmental engineering department, Faculty of engineering, Zagazig university, Egypt \\ ${ }^{b}$ Arab Academy for Science, Technology and Marine Transportation, , Egypt
}

\begin{abstract}
The increased demand for advanced techniques in anaerobic digestion over the last few years has led to the employment of various pre-treatment methods prior to anaerobic digestion to increase gas production. These pre-treatment methods alter the physical and chemical properties of sludge in order to make it more readily degradable by anaerobic digestion. Although the thermal pre-treatment presents high energy consumption, the main part of this energy to heat can be recovered from the biogas produced in the anaerobic process. In this research a mixture of primary and waste activated sludge was thermally pretreated at $100,125,150,175$ and $200{ }^{\circ} \mathrm{C}$ in order to determine the reaction kinetics for the increase of soluble organic fraction (expressed as CODs and VFAs). Experimental results proved that the solubilization of sludge is a $1^{\text {st }}$ order reaction with respect to both CODs and VFAs, $\mathrm{K}_{\mathrm{CODs}}$ (reaction rate constant of CODs solubilization) increased from $4.59 * 10^{-3}\left(\mathrm{~min}^{-1}\right)$ to $7.55^{*} 10^{-3}\left(\mathrm{~min}^{-1}\right)$ as the temperature increased from 100 to $200{ }^{\circ} \mathrm{C}$, with a reaction activation energy of $7447.21(\mathrm{~J} / \mathrm{mole})$ and frequency factor of $0.051\left(\mathrm{~min}^{-1}\right)$, While $\mathrm{K}_{\mathrm{VFAs}}$ (reaction rate constant of VFAs solubilization) increased from $5.33 * 10^{-3}\left(\mathrm{~min}^{-1}\right)$ to $7.97 * 10^{-3}\left(\mathrm{~min}^{-1}\right)$ for the same increase in temperature, with a reaction activation energy of $5947.22(\mathrm{~J} / \mathrm{mole})$ and frequency factor of $0.0364\left(\mathrm{~min}^{-1}\right)$.
\end{abstract}

Keywords: Anaerobic digestion, CODs, solubilization reaction kinetics, thermal pretreatment and VFAs.

\section{Introduction}

Anaerobic digestion plays an important role in wastewater treatment processes. It includes a series of biochemical processes by different microorganisms to degrade organic matter under anaerobic conditions. Methane, the digestion byproduct, is a rich source of renewable energy, which can help to replace fossil fuel to contribute to environmental conservation and sustainability (Pavlostathis et al, 1991). A major benefit is the large volume reduction of the sludge. Other beneficial features include stabilization of the sludge, inactivation and reduction of pathogens, and improvement of the sludge dewaterability (Apples et al, 2010), which is very important for further handling after AD. The main problem related to sludge treatment is its cost which usually ranges from

${ }^{*}$ Corresponding author. Tel.: 00201111784499

E-mail: aseaf_1@yahoo.com

(C) 2015 International Association for Sharing Knowledge and Sustainability

DOI: $10.5383 /$ ijtee.10.02.011
$20 \%$ to $60 \%$ of the total operating costs of the wastewater treatment plant (Marcos et al, 2005).

Activated sludge is resistant to anaerobic digestion. The cell contents are very degradable but they are protected by the tough cell walls. Biomass also holds onto water, so it is difficult to dewater (Garg 2009). Different strategies have been studied in order to enhance anaerobic digestion of sludge. Among those wet sludge technologies group various technologies that include physical, chemical, mechanical, biological, etc.

\subsection{Thermal Pretreatment}

Heat energy applied during thermal treatment acts by disrupting the chemical bonds of the cell wall and membrane, thus releasing the cell components into solution. Hiraoka et al. (1985) studied the effect of thermal pretreatment of sludge on subsequent anaerobic digestion when the pretreatment 
temperature is relatively low (below $100{ }^{\circ} \mathrm{C}$ ). The WAS was treated at 60,80 and $100{ }^{\circ} \mathrm{C}$ under pressurized conditions of 3 $\mathrm{Kg} / \mathrm{cm}^{2}$. For 60 and $80{ }^{\circ} \mathrm{C}$ VS reduction was not significantly improved. At $100{ }^{\circ} \mathrm{C}$ an improvement between 5 and $10 \%$ was observed. However, in terms of gas production, a maximum was reached at $60{ }^{\circ} \mathrm{C}$. The results obtained above were used to conduct a pilot plant study. The WAS was treated at $60{ }^{\circ} \mathrm{C}$ for 120 minutes with a pressure of $3 \mathrm{Kg} / \mathrm{cm}^{2}$. An increase in VS destruction between 2 and $9 \%$ was observed.

$\mathrm{Li}$ and Noike (1992) studied the effect of thermal treatment of waste activated sludge (WAS) by varying the temperature of pretreatment between 62 and $175^{\circ} \mathrm{C}$ and maintaining a constant treatment time of 30 minutes. Solubilization ratios increased from 25 to $45 \%$ as the temperature increased, except a decrease observed at $90^{\circ} \mathrm{C}$. To study the effect of thermal pretreatment on anaerobic digestion laboratory-scale chemostat-type experiments were conducted at SRTs of 1.5, 3, 5 and 10 days at $35^{\circ} \mathrm{C}$. The pretreatment temperatures used were $120,150,170$, and $175^{\circ} \mathrm{C}$ for 30 minutes. Both VSS degradation efficiency and the chemical oxygen demand (COD) removal efficiency were higher in all cases for pretreated sludge. The best results were obtained for a temperature of $1700 \mathrm{C}$ and SRT of 5 days, an increase of $30 \%$ in VSS degradation efficiency over the control was observed. Zheng et al. (1998) studied rapid thermal conditioning (RTC) of partially digested sludge at three different temperatures: 100,160 and $220{ }^{\circ} \mathrm{C}$ for 30 seconds. VS reductions of 10,20 , and $40 \%$ were obtained respectively. At $220{ }^{\circ} \mathrm{C}$ a small mineral solids reduction was also achieved. (WAS) was also treated at $220{ }^{\circ} \mathrm{C}$ for 30 seconds achieving a $55 \%$ VS reduction.

Bougrier et al. (2006) compared the thermal pretreatments (130 ${ }^{\circ} \mathrm{C}, \mathrm{pH}=10,150{ }^{\circ} \mathrm{C}$ and $170{ }^{\circ} \mathrm{C}$ during $30 \mathrm{~min}$ ) performance of waste activated sludge collected from urban wastewater plants with untreated sludge samples. The results indicated that there was positive effect on solubilization rates and methanization when thermal pretreatment was added. Particularly, the $170{ }^{\circ} \mathrm{C}$ treatment led to comparable results in anaerobic digestion performance increase: about $80 \%$ improvement in removal of matter and in biogas yield.

\section{Material and Methods}

In order to study the hydrolysis process of the sludge, a series of experiments were performed at different temperatures $\left(100,125,150,175\right.$ and $\left.200{ }^{\circ} \mathrm{C}\right)$. All determinations were carried out in duplicate. The sludge used in this study was a thickened combined municipal-primary and waste activated sludge- from conventional activated sludge WWTP located at Menia ElKamh, Sharquiah, Egypt. The sludge samples $(2.0 \mathrm{~L})$ was put in a glass beaker placed in an oven to maintain the desired reaction temperature. Chemical oxygen demand (COD), soluble chemical oxygen demand (CODs) and Volatile fatty acids (VFAs) were measured every (30, 60, 120, and 240 minutes). Chemical oxygen demand (COD) and soluble Chemical oxygen demand (CODS) was measured according to method (508) of standard methods (Standard Methods, 1985), For soluble COD, samples were first centrifuged at $3000 \mathrm{rpm}$ for 30 minutes and then filtered using $0.45 \mu \mathrm{m}$ filter before digestion. In this procedure the sample is heated in a COD meter, at $150^{\circ} \mathrm{C}$ for two hours in vials containing a strong oxidizing agent (potassium dichromate). During the reaction, the oxidizable organic fraction reduces the dichromate ion $\left(\mathrm{Cr}_{2} \mathrm{O}_{7}^{-2}\right)$ to green chromic ion $\left(\mathrm{Cr}^{+3}\right)$ then it was measured by titration method against FAS.
Volatile fatty acids were measured according to the method proposed by Kapp. (1984), (1992) and modified by Buchauer (1998) as follow

- Before analysis the sample is filtered through a 0.45 $\mu \mathrm{m}$ membrane filter. In the case of online application an ultra-filtration unit is used.

- Filtered sample $(20 \mathrm{ml})$ is put into a titration vessel, the size of which is determined by the basic requirement to guarantee that the tip of the $\mathrm{pH}$ electrode is always immersed below the liquid surface.

- Initial $\mathrm{pH}$ is recorded.

- The sample is titrated slowly with $0.1 \mathrm{~N}$ sulphuric acid until pH 5.0 is reached. The added volume of the titrant is recorded.

- More acid is slowly added until pH 4.3 is reached. The total volume of the added titrant is again recorded.

- The latter step is repeated until $\mathrm{pH} 4.0$ is reached, and the volume of added titrant recorded once more.

- A constant mixing of sample and added titrant is required right from the start to minimize exchange of $\mathrm{CO} 2$ with the atmosphere during titration. Depending on the system in use this is done via a small impeller or via a magnetic stirrer.

- Then substitute in the following equation to get VFA concentration

$V F A s=\frac{131340 \times N \times V_{4,5}}{V . S .}-\frac{3.08 \times N \times V_{4,3}}{V . S}-25$

Where

VFAs $=$ the required volatile fatty acid concentration in (p.p.m) $\mathrm{N}=$ the normality of the used acid

$\mathrm{V} 4,5=$ the volume of acid required to decrease $\mathrm{pH}$ from 5 to 4

$\mathrm{V} 4,3=$ the volume of acid required to decrease $\mathrm{pH}$ from initial $\mathrm{pH}$ to 4.3

V.S. = volume of sample

Table (1) shows the average concentration of raw thickened sludge used in this study.

Table 1. Raw sludge characteristics

\begin{tabular}{ll}
\hline Parameters & Sludge \\
$\mathrm{pH}$ & $6.1-6.5$ \\
$\mathrm{COD}(\mathrm{g} / \mathrm{l})$ & 57.80 \\
$\mathrm{CODs}(\mathrm{g} / \mathrm{l})$ & 3.10 \\
VFAs $(\mathrm{g} / \mathrm{l})$ & 2.00 \\
Ammonia (p.p.m) & $480-550$ \\
Color & Dark brown \\
\hline
\end{tabular}




\section{RESULTS}

\subsection{CODs solubilization}

Table (2) shows the CODs for the different tested temperatures $\left(100,125,150,175\right.$ and $\left.200{ }^{\circ} \mathrm{C}\right)$. The total COD concentration almost remains constant at the value of $57.80(\mathrm{~g} / \mathrm{l})$, the initial CODs for sludge were $3.10(\mathrm{~g} / \mathrm{l})$, which gives a solubilization ratio (CODs/COD) of $5.40 \%$. Increasing temperature and heating time increased the CODs solubilization ratio as it ranged between $14.36 \%$ and $28.8 \%$ at the end of the thermal pretreatment experiment. These results complies with the results of Yuan et al, (2011) and Val del rio et al, (2011).

Table 2. CODs concentration in $(\mathrm{g} / \mathrm{l})$ for the different tested thermal pretreatment temperatures

\begin{tabular}{llllll}
\hline \multirow{2}{*}{$\begin{array}{l}\text { Time } \\
(\mathrm{min})\end{array}$} & \multicolumn{6}{c}{ Thermal pretreatment temperature $\left({ }^{\circ} \mathrm{C}\right)$} \\
\cline { 2 - 6 } & 100 & 125 & 150 & 175 & 200 \\
\hline 0 & 3.10 & 3.10 & 3.10 & 3.10 & 3.10 \\
30 & 3.70 & 4.00 & 4.20 & 4.40 & 4.50 \\
60 & 4.80 & 5.00 & 5.50 & 6.50 & 6.80 \\
120 & 6.20 & 6.40 & 6.80 & 8.70 & 8.60 \\
240 & 8.30 & 10.60 & 11.20 & 14.50 & 16.20 \\
\hline
\end{tabular}

Now, in order to determine a mathematical model for the thermal pretreatment of sludge, the rate of CODs solubilization has to be determined. According to Batstone et al (2002) (IWA) the anaerobic digestion model NO 1 (ADM1) a first order reaction could be used for each step of the anaerobic digestion process. Equation 2 could be used to describe the relation between CODs and heating time.

$$
C O D s=C O D s_{0} \times e^{\left(k_{C O D s} \times t\right)}
$$

Where

CODs $=$ the Soluble COD concentration in $(\mathrm{g} / \mathrm{l})$.

$\mathrm{CODs}_{0}=$ the initial Soluble COD concentration in $(\mathrm{g} / \mathrm{l})$.

$\mathrm{K}_{\mathrm{CODs}}=$ reaction rate constant of CODs solubilization $\left(\mathrm{min}^{-1}\right)$.

$\mathrm{T}=$ Heating time $(\mathrm{min})$.

In order to prove that equation (2) is applicable for this study the relation between CODs and heating time for each thermal pretreatment temperature were tested against the proposed equation as shown in figure (1) the calculated $R^{2}$ values could be accepted so the reaction is a first order and the reaction rate constant of CODs solubilization could be determined and tabulated in table 3 .
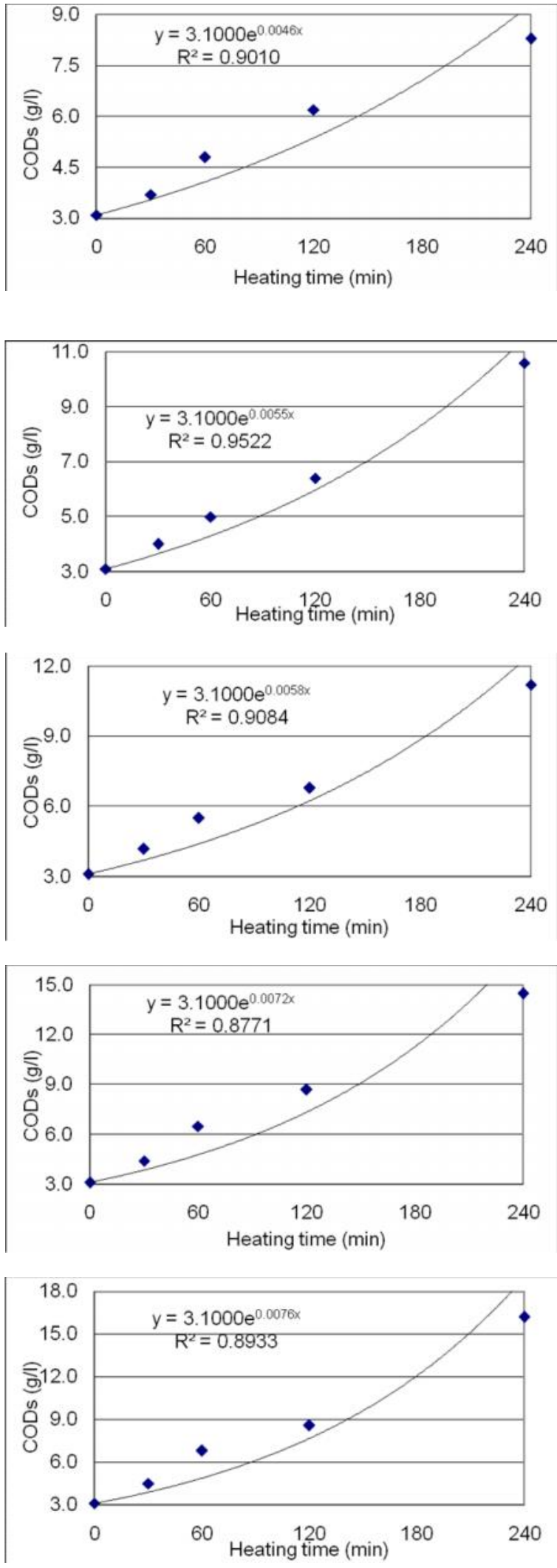

Figure (1) Relation between CODs and heating time for different pretreatment temperature. 
Table 3. Reaction rate constant for CODs solubilization

\begin{tabular}{ll} 
Heating temperature $\left({ }^{0} \mathrm{C}\right)$ & $\mathrm{K}_{\mathrm{CODs}}\left(\mathrm{min}^{-1}\right)$ \\
100 & $4.59 \mathrm{E}-03$ \\
125 & $5.47 \mathrm{E}-03$ \\
150 & $5.83 \mathrm{E}-03$ \\
175 & $7.18 \mathrm{E}-03$ \\
200 & $7.55 \mathrm{E}-03$ \\
\hline
\end{tabular}

\subsubsection{Effect of temperature on the reaction rate constant of} CODs solubilization

As the reaction temperature increased the rate of reaction increases. As a rough approximation, for many reactions happening at around room temperature, the rate of reaction doubles for every $10^{\circ} \mathrm{C}$ rise in temperature (chapra, 2000).

Arrhenius Equation (equation 3) could be used to determine the relation between reaction rate constant and pretreatment temperature

$$
K_{C O D s}=A \times e^{\left(\frac{-E_{a}}{R \times T_{a}}\right)}
$$

Where

$\mathrm{A}=$ frequency factor in $\left(\mathrm{min}^{-1}\right)$.

$E_{a}=$ reaction activation energy in $(\mathrm{J} / \mathrm{mole})$.

$\mathrm{R}=$ gas constant $(8.314 \mathrm{~J} / \mathrm{mole} \cdot \mathrm{K})$.

$\mathrm{T}_{\mathrm{a}}=$ Absolute Temperature $(\mathrm{K})$.

In order to determine frequency factor and reaction activation energy the relation between reaction rate constant for the CODs solubilization and $\left(1 / \mathrm{T}_{\mathrm{a}}\right)$ should be drawn as shown in Figure (2).

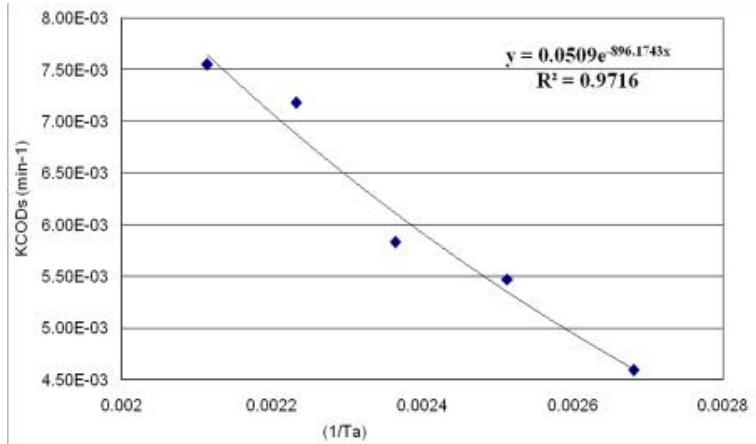

Figure (2) relation between reaction rate constant for the CODs solubilization and (1/Ta).

From figure (2) it was found that the CODs solubilization reaction has a reaction activation energy of $7447.21(\mathrm{~J} / \mathrm{mole})$ and frequency factor of 0.051 (min-1), and equation (2) could be rearranged to form equation (4) in order to incorporate the effect of the temperature

$C O D s=C O D s_{0} \times e^{\left(\left(0.0509 \times e \frac{896.17}{T_{a}}\right) \times t\right)}$

\subsection{VFAs solubilization}

Table (4) shows the VFAs for the different tested temperatures $\left(100,125,150,175\right.$ and $\left.200{ }^{\circ} \mathrm{C}\right)$, the initial VFAs for sludge were $2.00(\mathrm{~g} / \mathrm{l})$. The results show that increasing temperature and heating time increased the VFAs concentrations.

Table 4. VFAs concentration in $(\mathrm{g} / \mathrm{l})$ for the different tested thermal pretreatment temperatures

\begin{tabular}{llllll}
\hline \multicolumn{6}{c}{ Thermal pretreatment temperature $\left({ }^{\circ} \mathrm{C}\right)$} \\
Time $(\mathrm{min})$ & 100 & 125 & 150 & 175 & 200 \\
0 & 2.00 & 2.00 & 2.00 & 2.00 & 2.00 \\
30 & 2.40 & 2.55 & 2.70 & 2.85 & 2.90 \\
60 & 3.20 & 3.40 & 3.80 & 4.42 & 4.70 \\
120 & 4.55 & 4.60 & 5.00 & 6.40 & 6.20 \\
240 & 6.30 & 8.00 & 8.00 & 9.90 & 11.10 \\
\hline
\end{tabular}

Equation 2 could be transformed into equation (5).

$V F A s=V F A s_{0} \times e^{\left(k_{V F A s} \times t\right)}$

Where

VFAs $=$ the VFAs concentration in $(\mathrm{g} / \mathrm{l})$.

$\operatorname{VFAs}_{0}=$ the initial VFAs concentration in $(\mathrm{g} / \mathrm{l})$.

$\mathrm{K}_{\mathrm{VFAs}}=$ reaction rate constant of VFAs solubilization $\left(\mathrm{min}^{-1}\right)$.

$\mathrm{T}=$ Heating time $(\mathrm{min})$.

In order to prove that equation (5) is applicable for this study the relation between VFAs and heating time for each thermal pretreatment temperature were tested against the proposed equation as shown in figure (3) the calculated $R^{2}$ values could be accepted so the reaction is a first order and the reaction rate constant of VFAs solubilization could be determined and tabulated in table 5 .

Table 5. Reaction rate constant for VFAs solubilization

\begin{tabular}{ll}
\hline Heating temperature $\left({ }^{0} \mathrm{C}\right)$ & $\overline{\mathrm{K}_{\text {VFAs }}\left(\mathrm{min}^{-1}\right)}$ \\
100 & $5.33 \mathrm{E}-03$ \\
125 & $6.17 \mathrm{E}-03$ \\
150 & $6.41 \mathrm{E}-03$ \\
175 & $7.60 \mathrm{E}-03$ \\
200 & $7.97 \mathrm{E}-03$ \\
\hline
\end{tabular}

\subsubsection{Effect of temperature on the reaction rate constant of} VFAs solubilization

In order to determine frequency factor and reaction activation energy the relation between reaction rate constant for the VFAs solubilization and $\left(1 / \mathrm{T}_{\mathrm{a}}\right)$ should be drawn as shown in Figure (4). 

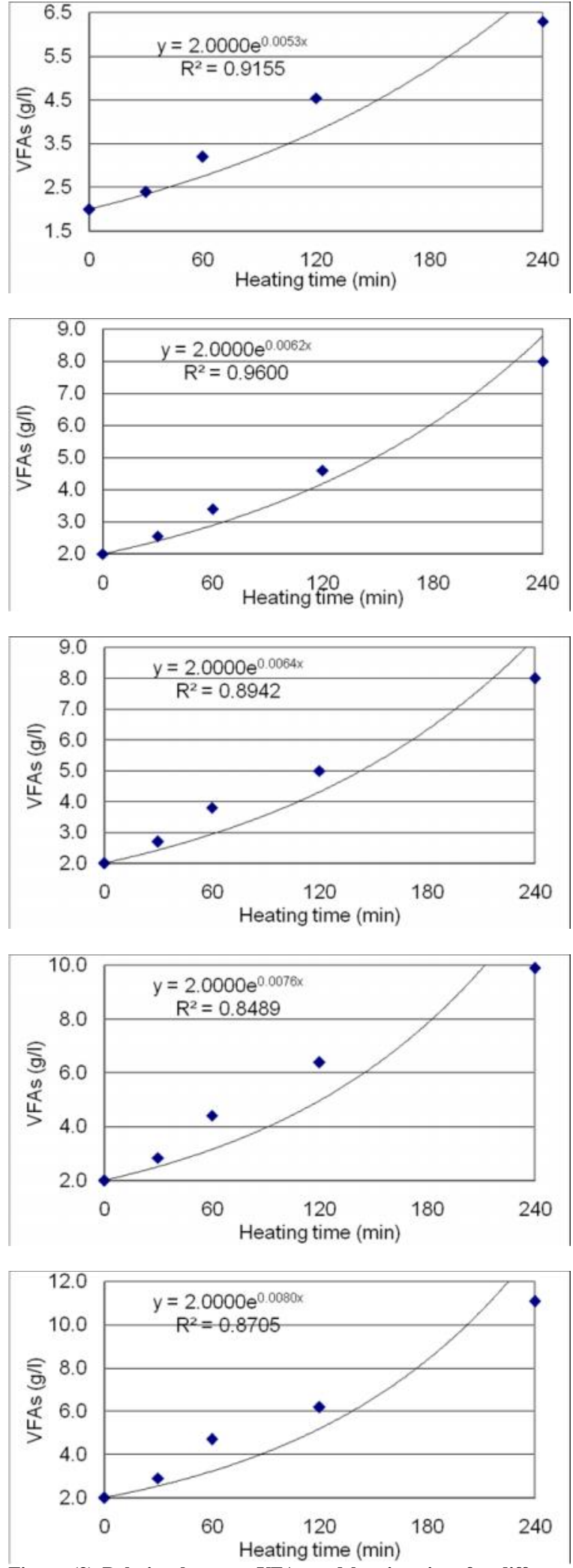

Figure (3) Relation between VFAs and heating time for different pretreatment temperature.

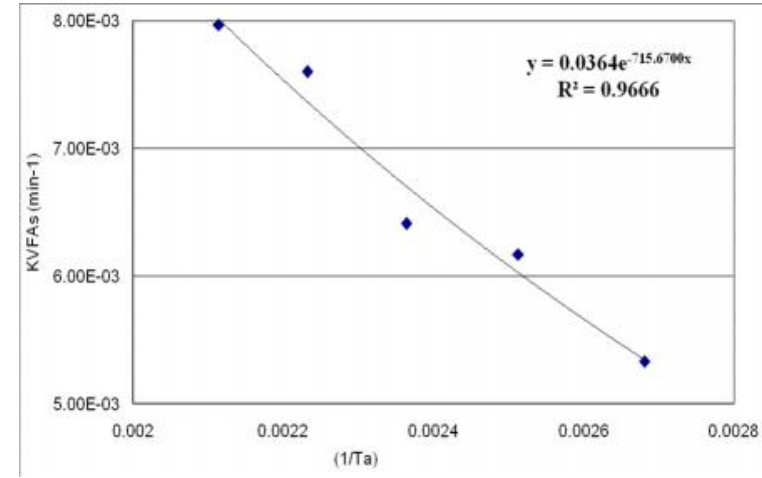

Figure (4) relation between reaction rate constant for the VFAs solubilization and (1/Ta).

From figure (4) it was found that the VFAs solubilization reaction has a reaction activation energy of $5947.22(\mathrm{~J} / \mathrm{mole})$ and frequency factor of 0.0364 (min-1), and equation (5) could be transformed into equation (4) in order to incorporate the effect of the temperature

$V F A s=V F A s_{0} \times e^{\left(\left(0.0364 \times e \frac{715.47}{T_{a}}\right) \times t\right)}$

\section{Conclusion}

It has been known for many years that a thermal pretreatment can improve the degradability of sludge. While the carbohydrates and the lipids of the sludge are easily degradable, the proteins are protected from the enzymatic hydrolysis by the cell wall. Heat applied during thermal treatment destroyed the chemical bonds of the cell wall and membrane, thus makes the proteins accessible for biological degradation. In this research a mixture of primary and waste activated sludge was thermally pretreated at 100, 125, 150, 175 and $200{ }^{\circ} \mathrm{C}$. from the experimental results the following conclusions could be derived

- The solubilization of sludge is a $1^{\text {st }}$ order reaction with respect to both CODs and VFAs.

- Increasing heating time or heating temperature increased the solubilization process.

- The CODs solubilization reaction had a reaction activation energy of $7447.21(\mathrm{~J} / \mathrm{mole})$ and frequency factor of $0.051\left(\mathrm{~min}^{-1}\right)$,

- The VFAs solubilization reaction had a reaction activation energy of $5947.22(\mathrm{~J} / \mathrm{mole})$ and frequency factor of $0.0364\left(\mathrm{~min}^{-1}\right)$. 


\section{References}

[1] Appels, L., Degrève, J., Van der Bruggen, B., Van Impe, J., Dewil, R., (2010). Influence of low temperature thermal pre-treatment on sludge solubilisation, heavy metal release and anaerobic digestion. Bioresour. Technol. 101, 5743-5748.

[2] Batstone, D. J.; Keller, J.; Angelidaki, I.; Kalyuzhnyi, S. V.; Pavlostathis, S. G.; Rozzi, A.; Sanders, W. T. M.; Siegrist, H.; Vavilin, V. A. (2002): The IWA Anaerobic Digestion Model No 1 (ADM1). Water Science and Technology, Vol. 45, No. $10,65-73$.

[3] Bougrier C., Delgene`s J.-P. \& Carre`re H. (2006). Combination of thermal treatments and anaerobic digestion to reduce sewage sludge quantity and improve biogas yield. Process Safety and Environmental Protection, 84(B4):280-284.

[4] Buchauer K (1998) “A comparison of two simple titration procedures to determine volatile fatty acids in influents to waste-water and sludge" Water SA Vol. 24 No. 1, 49-56.

[5] Chapra S.C. (2000) "Surface Water Quality Modeling. International Editions McGraw-Hill Companies, Inc.

[6] Garg, N.K (2009)"Multi-criteria Assessment of Alternative Sludge Disposal Methods" M.sc. thesis, University of Strathclyde, Scotland.
[7] Hiraoka, M., Takeda, N., Sakai, S., Yasuda, A., (1985) "Highly efficient anaerobic digestion with thermal pretreatment". Wat. Sci. Tech. 17, 529-539.

[8] Li, Y.Y., Noike, T., (1992) "Upgrading of anaerobic digestion of waste activated sludge by thermal pretreatment. Wat. Sci. Tech. 26, 857-866.

[9] Marcos von Sperling: Carlos A. Chernicharo, (2005) "Biological wastewater treatment in warm climate regions". IWA Publishing, USA.

[10] Pavlostathis, S.G. and Giraldo-Gomez, E. (1991) Kinetics of anaerobic treatment: A critical review. Critical Reviews in Environmental Control 21(5-6), 411-490

[11] Val del Ri, N. Morales, E. Isanta, A. MosqueraCorral ,J.P. Steyer, H. Carrere (2011) "Thermal pretreatment of aerobic granular sludge: Impact on anaerobic biodegradability" water research 45,6011 6020

[12] Yuan Q., Sparling R., Oleszkiewicz J.A. (2011) "Technical Note: VFA generation from waste activated sludge: Effect of temperature and mixing" Chemosphere 82, 603-607.

[13] Zheng, J., Graff, R.A., Fillos, J., Rinard, I., (1998) "Incorporation of rapid thermal conditioning into a wastewater treatment plant". Fuel Processing Technology 56, 183-200. 